\title{
EFEKTIVITAS PEMBELAJARAN PETA KONSEP DALAM MENINGKATKAN HASIL BELAJAR MATEMATIKA MATERI KESEBANGUNAN DAN KEKONGRUENAN DITINJAU DARI KREATIVITAS
}

\author{
${ }^{1)}$ Jonner Nainggolan; ${ }^{2)}$ Humisar BTPJ Pasaribu \\ ${ }^{1)}$ Jurusan Matematika Universitas Cenderawasih; jonner2766@gmail.com \\ ${ }^{2)}$ FKIP Universitas Cenderawasih; p.humisar1606@ gmail.com
}

\begin{abstract}
The purpose of this study was to determine whether the mathematics learning outcomes on the congruence and congruence material taught by concept maps were better than students taught by conventional methods. The variables in this study were two independent variables (1) learning methods, and (2) students' creativity and one dependent variable, namely mathematics learning outcomes. The sample in this study were students of class IX B and IX E SMP Negeri 2 Abepura Jayapura. Data collection methods used in this study are: documentation, questionnaires and test methods. Questionnaires and tests used to retrieve data in research before use were tested for validity and reliability. The processed data is data that is normally distributed and homogeneous. The results of the study showed that students' mathematics learning outcomes on the similarity and congruence material taught with concept maps were better than those taught by conventional methods. Mathematics learning outcomes of students on similarity and congruence materials that have high creativity are better than moderate creativity. The mathematics learning outcomes of students on similarity and congruence materials that have moderate creativity are better than low creativity.
\end{abstract}

Key words: learning outcomes; creativity; concept maps; conventional method.

\begin{abstract}
ABSTRAK
Tujuan penelitian ini adalah untuk mengetahui apakah hasil belajar matematika pada materi kesebangunan dan kekongruenan yang diajar dengan peta konsep lebih baik dari pada peserta didik yang diajar dengan metode konvensional. Variabel dalam penelitian ini adalah dua variabel bebas (1) metode pembelajaran, dan (2) kreativitas peserta didik dan satu variabel terikat yaitu hasil belajar matematika. Sampel dalam penelitian ini adalah peserta didik kelas IX B dan IX E SMP Negeri 2 Abepura Jayapura. Metode pengumpulan data yang digunakan dalam penelitian ini adalah: dokumentasi, angket dan metode tes. Kuisioner dan tes yang digunakan untuk mengambil data dalam penelitian sebelum digunakan diuji validitas dan reliabilitasnya. Data yang diolah merupakan data yang berdistribusi normal dan homogen. Hasil penelitian diperoleh hasil belajar matematika peserta didik pada materi kesebangunan dan kekongruenan yang diajar dengan peta konsep lebih baik daripada yang diajar dengan metode konvensional. Hasil belajar matematika peserta didik pada materi kesebangunan dan kekongruenan yang memiliki kreativitas tinggi lebih baik daripada kreativitas sedang. Hasil belajar matematika peserta didik pada materi kesebangunan dan kekongruenan yang memiliki kreativitas sedang lebih baik daripada kreativitas rendah.
\end{abstract}

Kata kunci: Hasil belajar; kreativitas ; peta konsep; metode konvensional.

\section{PENDAHULUAN}

Belajar matematika dimulai dari urutan yang sederhana menuju pada hal-hal yang lebih kompleks. Materi suatu konsep adalah prasyarat harus diajarkan lebih dahulu, apabila konsep tersebut akan diperlukan pada pengajaran materi 
berikutnya. Faktor dominan yang mempengaruhi pada proses pembelajaran adalah guru (Usman, M.U., 2001). Peserta didik memerlukan pengetahuan mengenai konsep-konsep maupun prinsip-prinsip yang mendasarinya untuk mencapai penguasaan matematika. Pemahaman konsep merupakan dasar dari pemahaman prinsip dan teori, karena untuk dapat memahami prinsip dan teori, peserta didik harus memahami terlebih dulu konsepkonsep yang menyusun prinsip dan teori tersebut. Apabila peserta didik kurang memahami fakta, konsep-konsep dan prinsip-prinsip dasar matematika akan sulit untuk menggeneralisasikan atau mengaitkan dalam kehidupan sehari-hari (Setiawati, E. 2005).

Sebuah metode dapat digunakan ketika metode tersebut memang cocok. Terkait dengan hal tersebut, peneliti tertarik terhadap suatu cara yang dapat diterapkan dalam pembelajaran di sekolah, Heriawan (2012), yang menyebutkan bahwa peta konsep merupakan suatu metode, dan peta konsep tersebut sudah diterapkan dalam berbagai penelitian.

Materi kesebangunan dan kekongruenan merupakan salah satu materi pokok yang sering dianggap sulit oleh para peserta didik karena materi ini terdiri dari fakta, konsep, prinsip, rumus dan definisi yang saling berkaitan satu sama lain. Dalam penyampaian materi yang mempunyai karakteristik seperti ini diharapkan peserta didik tidak hanya mengingat dan menghafal rumus tetapi juga dapat menemukan hubungan konsepkonsep yang ada dalam materi yang sedang dipelajari.

Peta konsep memperlihatkan bagaimana konsep-konsep saling terkait. Untuk menyusun peta konsep diperlukan konsep-konsep dan kata-kata yang menghubungkan konsep-konsep menjadi proposisi yang bermakna. Peta konsep melatih peserta didik untuk membuat peta konsep sendiri. Untuk menghasilkan peta konsep, peserta didik tidak hanya sekedar membaca dan menghafal, tetapi juga berusaha untuk menemukan hubungan yang ada dalam materi yang sedang dipelajari. Melalui peta konsep, setiap potongan informasi baru akan saling terkait dengan semua informasi yang sudah adasebelumnya. Terkait dengan beberapa pernyataan tersebut dapat disimpulkan bahwa peta konsep bisa dijadikan alternatif dalam model-model pembelajaran di sekolah(Yanti, S. 2009).

Beberapa penelitian telah dilakukan terkait dengan penggunaan peta konsep, yaitu "Implementasi Strategi Peta Konsep dalam Usaha Membangun Pemahaman Konsep Fungsi Komposisi Peserta Didik" (Yanti, S. 2009) dan "Meningkatkan Kemampuan Pemahaman dan Kemampuan Pemecahan Masalah Matematika Melalui 
Teknik SQ4r dan Peta Konsep Peserta Didik SMA Negeri 2 Kota Bandung" (Setiawati, E. 2005). Kedua judul penelitian tersebut merupakan contoh penelitian yang telah dilakukan dengan menggunakan peta konsep (Mind Mapping). Kedua penelitian tersebut, merupakan penelitian dalam bidang pendidikan matematika.

Oleh karena itu, berdasarkan uraian di atas maka penulis mencoba melakukan penelitian yang berjudul "Efektivitas Pembelajaran Peta Konsep dalam Meningkatkan Hasil Belajar Matematika Materi Kesebangunan dan Kekongruenan pada Peserta Didik Kelas IX SMP Negeri 2 Jayapura Ditinjau dari Kreativitas”.

\section{METODE PENELITIAN}

Populasi dalam penelitian ini adalah seluruh peserta didik kelas IX SMP Negeri II Kota JayapuraTahun Pelajaran 2018/2019.Teknikpengambilan sampel yang digunakan dalam penelitian ini adalah teknik stratified cluster random sampling, yaitu kombinasi antara statified random samplingdan cluster random sampling. Dalam penelitian ini peserta didik kelas IXE dan peserta didik kelas IXG. Penelitian dilaksanakan pada tanggal 18-30 Mei 2020. Pada variable dalam tulisanya itu dua variabel bebas dan satu variabel terikat yaitu: Variabel bebasnya: (1) Metode pembelajaran dan (2) Kreativitas belajar peserta didik, sedangkan variable terikatnya adalah hasil belajar peserta didik.

Metode yang digunakan untuk mengumpulkan data yaitu metode dokumentasi, metode angket, dan metodetes. Instrumen yang digunakan dalam penelitian ini adalah tes. Sebelum diberikan tes, dilakukan uji validitas dan reliabilitas, soal yang digunakan dalam pengambilan data adalah soal yang valid dan yang reliable. Rumus uji validitas yang digunakan adalah:

$r$ hitung dengan menggunakan korelasi produk momen Karl Pearson sebagai berikut:

$$
r_{x y}=\frac{n \sum X Y-\sum(X) \sum(Y)}{\sqrt{\left(n \sum X^{2}-\left(\sum X\right)^{2}\right)\left(n \sum Y^{2}-\left(\sum Y\right)^{2}\right)}},
$$

dengan: $r_{x y}=$ indeks daya pembeda untuk butir ke- $i, n \quad=$ cacah subyek yang dikenai tes, $X=$ skor untuk butir ke $j, Y=$ skor total, denganr $r_{\text {tabel }}=r_{(\alpha=0,05,} n-$ i).Jika $r_{x y}>\mathrm{r}_{\text {tabel }}$ maka soal tersebut valid dan sebaliknya dan soal yang digunakan untuk mengambil data penelitian adalah soal yang valid. Untuk menghitung reliabilitas angket dalam penelitian ini digunakan rumus Alpha sebagai berikut:

$$
r_{11}=\left(\frac{n}{n-1}\right)\left(1-\frac{\sum s b^{2}}{S t^{2}}\right),
$$

dengan: $r_{11}=$ indeks reliabilitas instrumen, $n=$ banyaknya butir instrumen, $S b^{2}$ $=$ variansi butir, $S t^{2}=$ variansi total, dengan $r_{\text {tabel }}=r_{(\alpha=0,05, n-1) . J i k a} r_{11}>r_{\text {tabel }}$ maka soal tersebut reliable dan sebaliknya (Budiono, 1990). 
Sebelum dilakukan analisis data dilakukan dahulu uji persyaratanya itu uji normalitas dan uji homogenitas. Untuk mengetahui data tersebut berdistribusi normal atau tidak dan mempunyai variansi yang homogen atau digunakan alat bantu program SPSS 16.0 (Trihendradi, C., 2013)

\section{HASIL DAN PEMBAHASAN}

Hasil uji normalitas kemampuan awal untuk masing-masing kelas, baik kelas eksperimen maupun kelas kontrol semuanya berasal dari populasi yang berdistribusi normal. Hasil uji validitas yang dilakukan menyatakan validitas dari instrumen yang berupa tes berbentuk pilihan ganda sebanyak 15 butir soal, yang valid 10 soal yang digunakan sebagai soal dalam penelitian. Uji reliabilitas instrumen pada penelitian ini menggunakan uji Kuder Richardson KR-20 yaitu untuk menghitung koefisien reliabilitas instrumen tes. Dari hasil perhitungan diperoleh koefisien reliabilitas instrumen sebesar 0,669.

\section{Data Skor Angket Kreativitas Peserta didik}

Data skor angket kreativitas peserta didik dikumpulkan menggunakan Instrumen angket yang dilakukan setelah berakhirnya pembelajaran. Data skor kreativitas peserta didik secara keseluruhan mempunyai rata - rata $\bar{X}=54,53$ dan simpangan baku $s=12,384$. Selanjutnya data skor kreativitas peserta didik dikelompokkan ke dalam tiga kategori yaitu kreativitas tinggi, sedang dan rendah. Kreativitas tinggi adalah peserta didik yang mempunyai skor $>65$; kreativitas sedang adalah peserta didik yang mempunyai skor $48 \leq$ skor angket $\leq 65$ dan kreativitas rendah adalah peserta didik yang mempunyai skor $<48$.

\section{Data Hasil Belajar Matematika Untuk Peserta didik Kelas Eksperimen}

Data hasil belajar matematika peserta didik dikumpulkan dengan menggunakan tes dilakukan setelah berakhirnya pembelajaran peta konsep. Data hasil belajar matematika peserta didik untuk kelas eksperimen yaitu dari SMP Negeri 2 Jayapura, peserta didik masing-masing merupakan kelompok dengan kreativitas tinggi, sedang dan rendah.

\section{Data Hasil Belajar Matematika Untuk \\ Peserta didik Kelas Kontrol}

Pengambilan data hasil belajar matematika peserta didik dengan menggunakan instrumen tes yang sama dengan kelas eksperimen dilakukan setelah berakhirnya pembelajaran konvensional. Data hasil belajar matematika peserta didik untuk kelas kontrol yaitu dari SMP Negeri 2 Jayapura, peserta didikmasing-masing merupakan kelompok dengan kreativitas tinggi, sedang dan rendah (Tabel 1). 
Tabel 1. Rangkuman Deskripsi Data Hasil Belajar Matematika

\begin{tabular}{|c|l|c|c|c|}
\hline No & Kelompok & $\begin{array}{c}\text { Nilai } \\
\text { Ter- } \\
\text { tinggi }\end{array}$ & $\begin{array}{c}\text { Nilai } \\
\text { Ter- } \\
\text { rendah }\end{array}$ & $\begin{array}{c}\text { Rata- } \\
\text { Rata } \\
(\mathrm{X})\end{array}$ \\
\hline 1 & Eksperimen & 10 & 3,75 & 6,92 \\
\hline 2 & Kontrol & 10 & 3,75 & 6,5 \\
\hline 3 & $\begin{array}{l}\text { Kreativitas } \\
\text { Tinggi }\end{array}$ & 10 & 8,75 & 9,5 \\
\hline 4 & $\begin{array}{l}\text { Kreativitas } \\
\text { Sedang }\end{array}$ & 8,75 & 5 & 6,65 \\
\hline 5 & $\begin{array}{l}\text { Kreativitas } \\
\text { Rendah }\end{array}$ & 5 & 3,75 & 4,6 \\
\hline
\end{tabular}

\section{Uji Komparasi Ganda}

Uji komparansi kedua antar baris homogenya maka tidak perlu dilakukan uji lanjut pasca anava (uji komparasi antar baris). Untuk mengetahui metode mana yang memberikan efek lebih baik terhadap hasil belajar matematika peserta didik cukup dengan membandingkan besaran rataan marginalnya (rataan antar barisnya) saja. Rangkuman besaran rataan antar sel dan rataan marginal dapat dilihat pada Tabel 2 berikut:

Tabel 2. Rangkuman Rataan Antar Sel dan Rataan Marginal

\begin{tabular}{|l|c|c|c|}
\hline \multirow{2}{*}{$\begin{array}{l}\text { Metode } \\
\text { Pembela- } \\
\text { jaran }\end{array}$} & \multicolumn{3}{|c|}{ Kreativitas } \\
\cline { 2 - 4 } & Tinggi & Sedang & Rendah \\
\hline Peta & 9,583 & 6,667 & 5,00 \\
$\begin{array}{l}\text { konsep } \\
\text { konvensi- } \\
\text { onal }\end{array}$ & 9,375 & 6,625 & 4,67 \\
\hline $\begin{array}{l}\text { Rataan } \\
\text { marginal }\end{array}$ & 9,479 & 6,646 & 4,835 \\
\hline
\end{tabular}

Berdasarkan Tabel 2 tampak bahwa rataan hasil belajar matematika peserta didik yang diajarkan dengan peta konsep lebih besardari rataan hasil belajar matematika peserta didik yang diajarkan dengan metode konvensional. Jadi, dapat disimpulkan bahwa hasil belajar matematika dengan pembelajaran matematika dengan menggunakan peta konsep lebih baik dari pada yang diajarkan menggunakan metode konvensional.

\section{Pengujian HipotesisPenelitian}

Untuk menguji hipotesis dalam penelitian ini dilakukan dengan analisis varian dua jalan dengan sel tidak sama dan taraf $\quad$ signifikansi $\alpha=0,05 . \quad$ Hasil perhitungan analisis varian dua jalan dengan sel tidak sama disajikan seperti pada Tabel 3 berikut:

Tabel 3 Rangkuman Hasil Analisis Variansi Dua Jalan dengan Sel Tak Sama.

\begin{tabular}{|l|c|c|c|c|}
\hline $\begin{array}{c}\text { Sumber } \\
\text { Varian }\end{array}$ & $\mathrm{RK}$ & $\mathrm{F}_{\text {hit }}$ & $\mathrm{F}_{\alpha(0,05)}$ & $\begin{array}{c}\text { Kepu- } \\
\text { tusan } \\
\text { Uji }\end{array}$ \\
\hline Metode (A) & 0,686 & 0,406 & 4,26 & $\begin{array}{c}\text { Terima } \\
H_{0 \mathrm{~A}}\end{array}$ \\
\hline $\begin{array}{l}\text { Kreativitas } \\
\text { (B) }\end{array}$ & 32,002 & 18,955 & 3,40 & $\begin{array}{c}\text { Tolak } \\
H_{0 \mathrm{~B}}\end{array}$ \\
\hline $\begin{array}{l}\text { Interaksi } \\
\text { (AB) }\end{array}$ & 0,357 & 0,212 & 3,40 & $\begin{array}{c}\text { Terima } \\
H_{0 \mathrm{AB}}\end{array}$ \\
\hline Galat & 1,688 & - & - & - \\
\hline
\end{tabular}

Hasil perhitungan yang disajikan pada Tabel 3 menunjukkan bahwa : (1) Pada efek utama A (metode pembelajaran) harga statistik uji $F_{\text {hit }}=0,406 \operatorname{dan} F_{\alpha}=$ $F_{0,05 ; 1 ; 24}=4,26 \quad$ sehingga $\quad F_{\text {hit }}<F_{\alpha}$ dengan demikian $H_{0 \mathrm{~A}}$ diterima. Hal ini berarti tidak terdapat efek antar baris antara efektivitas metode pembelajaran peta konsep dengan metode pembelajaran konvensional terhadap hasil belajar 
matematika. Pada efek utama B (kreativitas peserta didik) harga statistik uji $F_{\text {hit }}=18,955 \quad$ dan $\quad F_{\alpha}=F_{0,05 ; 2 ; 24}=$ 3,40 sehingga $\quad F_{\text {hit }}>F_{\alpha} \quad$ demikian $H_{0 \mathrm{~B}}$ ditolak. Hal ini berarti terdapat efek antar kolom hasil belajar matematika antara kelompok kreativitas tinggi, sedang dan rendah. (2) Pada efek AB (metode pembelajaran dan tingkat kreativitas peserta didik) harga statistik uji $F_{\text {hit }}=$ 0,212dan $F_{\alpha}=F_{0,05 ; 2 ; 24}=3,40$ sehingga $F_{\text {hit }}<F_{\alpha}$ dengan demikian $H_{0 \mathrm{AB}}$ diterima. Hal ini berarti tidak ada interaksi antara metode pembelajaran dan tingkat kreativitas peserta didik terhadap hasil belajar matematika.

Hipotesis pertama adalah "Pembelajaran dengan peta konsep menghasilkan belajar matematika lebih baik dari pada pembelajaran dengan metode konvensional pada materi kesebangunan dan kekongruenan”. Berdasarkan hasil analisis varian dua jalan dengan sel tak sama untuk efek utama A (metode pembelajaran) diperoleh $F_{\text {hit }}=$ 0,406 dan $F_{\alpha}=F_{0,05 ; 1 ; 24}=4,26$ sehingga $F_{\text {hit }}<F_{\alpha}$ maka $H_{0 A}$ diterima.Hal ini berarti tidak terdapat efek antar baris antara efektivitas pembelajaran peta konsep dengan metode pembelajaran konvensional terhadap hasil belajar matematika pada materi kesebangunan dan kekongruenan. Karena $H_{0 A}$ diterima maka cukup dengan membandingkan rataan marginal untuk masing-masing metode tersebut.

Jika dilihat dari rataan marginal hasil belajar matematika yang diajarkan dengan peta konsep yaitu 7,0833 lebih besar dari rataan marginal hasil belajar matematika yang diajarkan dengan metode konvensional yaitu 6,89. Hasil ini sesuai dengan hipotesis penelitian dan juga sejalan dengan hasil penelitian yang dilakukan pembelajaran dengan menggunakan peta konsep. Hal ini diakibatkan bahwa dengan menggunakan peta konsep yang dilengkapi dengan LKS memudahkan para peserta didik untuk memahami konsep-konsep maupun keterkaitan antar konsep tersebut yang pada akhirnya membantu para peserta didik untuk mampu menyelesaikan permasalahan (soal-soal) pada materi kesebangunan dan kekongruenan. Sedangkan pada pembelajaran konvensional dimana guru langsung menekankan penggunaan rumus dan algoritma dan peserta didik dilatih mengerjakan soal-soal secara mekanik yang mana konsekwensinya jika peserta didik diberikan soal yang berbeda dengan soal-soal latihan maka mereka akan kesulitan dalam mengerjakannya.

Hasil belajar matematika peserta didik yang diajarkan dengan peta konsep lebih baik dari padahasil belajar matematika yang diajarkan dengan metode konvensional. Hasil analisis varian dua 
jalan dengan sel tak sama pada efek utama B (kreativitas peserta didik) diperoleh $F_{\text {hit }}=18,955 \quad$ dan $\quad F_{\alpha}=$ $F_{0,05 ; 2 ; 24}=3,40$ sehingga $F_{\text {hit }}>F_{\alpha}$ maka $H_{0 B}$ ditolak. Hal ini berarti peserta didik dengan kreativitas tinggi lebih baik hasil belajar matematikanya dibandingkan peserta didik yang mempunyai kreativitas sedang. Karena $H_{0 B}$ ditolak maka perlu dilakukan uji lanjut pasca anava yaitu uji komparasi ganda antar kolom. Hal ini berarti terdapat perbedaan hasil belajar matematika antara peserta didik yang memiliki kreativitas tinggi dengan peserta didik yang memiliki kreativitas sedang. Selanjutnya jika dilihat dari rataan marginal masing-masing tingkat kreativitas peserta didik yaitu kreativitas tinggi rataan hasil belajar matematikanya 9,479 lebih besar dari rataan hasil belajar matematika peserta didik yang memiliki kreativitas sedang yaitu 6,646. Artinya bahwa peserta didik dengan kreativitas tinggi lebih baik hasil belajar matematikanya dibandingkan denganpeserta didik dengan kreativitas sedang.

Hasil uji komparasi ganda antar kolom seperti dikemukakan di atas nampak bahwa tingkatan kreativitas peserta didik lebih baik terhadap hasil belajar matematika khususnya pada materi kesebangunan dan kekongruenan, artinya bahwa peserta didik dengan kreativitas tinggi lebih baik hasil belajar matematikanya dibanding dengan peserta didik yang memiliki kreativitas sedang. Hal tersebut disebabkan bahwa peserta didik yang memiliki kreativitas tinggi akan lebih mudah memahami konsep-konsep pada materi kesebangunan dan kekongruenan, karena kreativitas peserta didik merupakan kemampuan peserta didik menciptakan atau memodifikasi cara belajar atau mengolah informasi sehingga peserta didik tersebut mudah memahami atau mengerti tentang suatu konsep atau suatu materi pelajaran. Sebaliknya peserta didik yang memiliki kreativitas sedang karena kurang menciptakan atau memodifikasi cara belajar yang baik sehingga berakibat pada kurangnya kemampuan mereka dalam memahami suatu konsep atau suatu materi pelajaran. Hasil belajar matematika peserta didik dengan kreativitas tinggi lebih baik dari pada hasil belajar matematika peserta didik dengan kreativitas sedang.

Hipotesis ketiga "Peserta didik yang mempunyai kreativitas sedang, hasil belajarnya lebih baik dibandingkan dengan peserta didik yang mempunyai kreativitas rendah pada materi kesebangunan dan kekongruenan". Hasil analisis varian dua jalan dengan sel tak sama pada efek utama B (kreativitas peserta didik) diperoleh $F_{\text {hit }}=18,955 \quad$ dan $\quad F_{\alpha}=F_{0,05 ; 2 ; 24}=$ 3,40 sehingga $F_{\text {hit }}>F_{\alpha}$ maka $H_{0 B}$ ditolak. Hal ini berartipeserta didik dengan kreativitas sedang lebih baik hasil belajar matematikanya dibandingkan peserta didik 
yang mempunyai kreativitas rendah. Karena $H_{O B}$ ditolak maka perlu dilakukan uji lanjut pasca anava yaitu uji komparasi ganda antar kolom. Hal ini berarti terdapat perbedaan hasil belajar matematika antara peserta didik yang memiliki kreativitas sedang dengan peserta didik yang memiliki kreativitas rendah. Selanjutnya jika dilihat dari rataan marginal masing-masing tingkat kreativitas peserta didik yaitu kreativitas sedang rataan hasil belajar matematikanya 6,646 lebih besar dari rataan hasil belajar matematika peserta didik yang memiliki kreativitas rendah yaitu 4,835 . Artinya bahwa peserta didik dengan kreativitas sedang lebih baik hasil belajar matematikanya dibandingkan dengan peserta didik dengan kreativitas rendah.

Berdasarkan hasil uji komparasi ganda antar kolom seperti dikemukakan di atas nampak bahwa tingkatan kreativitas peserta didik lebih baik terhadap hasil belajar matematika khususnya pada materi kesebangunan dan kekongruenan, artinya bahwa peserta didik dengan kreativitas sedang lebih baik hasil belajar matematikanya dibanding dengan peserta didik yang memiliki kreativitas rendah. Hal tersebut disebabkan bahwa peserta didik yang memiliki kreativitas sedang akan lebih mudah memahamikonsepkonsep pada materi kesebangunan dan kekongruenan, karena kreativitas peserta didik merupakan kemampuan peserta didik menciptakan atau memodifikasi cara belajar atau mengolah informasi sehingga peserta didik tersebut mudah memahami atau mengerti tentang suatu konsep atau suatu materi pelajaran.

Berdasarkan hasil uji serta pembahasan di atas dapat disimpulkan bahwa hasil belajar matematika peserta didik dengan kreativitas sedang lebih baik dibandingkan dengan hasil belajar matematika peserta didik dengan kreativitas rendah.

Hipotesis keempat adalah "Hasil belajar matematika pada materi kesebangunan dan kekongruenan yang diajarkan dengan peta konseplebih baik daripada yang diajarkan dengan metode konvensional pada masing-masing peserta didik dengan kreativitas tinggi, sedang dan rendah". Hasil analisis variansi dua jalan dengan sel tak sama diperoleh $F_{\text {hit }}=$ 0,212 dan $\quad F_{\alpha}=F_{0,05 ; 2 ; 24}=3,40$. keputusan uji adalah $\mathrm{H}_{0 \mathrm{AB}}$ diterima. Karena $H_{O A B}$ diterima maka tidak perlu dilakukan uji lanjut pasca anava, sehingga perbandingan sel antar kolom dalam satu baris mengikuti perlakuan yang ada pada induknya yaitu efek utama A (metode pembelajaran) maupun efek utama $B$ (kreativitas peserta didik). Kesimpulan $H_{0 A B}$ diterima berarti tidak terdapat interaksi antara metode pembelajaran dan tingkat kreativitas peserta didik terhadap 
hasil belajar matematika pada materi kesebangunan dan kekongruenan. Hal ini berarti bahwa peserta didik yang diajarkan dengan peta konsep mempunyai hasil belajar matematika lebih baik dari pada peserta didik yang diajarkan dengan metode konvensional baik secara umum maupun kalau ditinjau dari masing-masing tingkatan kreativitas peserta didik. Hasil ini sejalan dengan pendapat para ahli yang mengatakan bahwa penggunaan peta konsep dalam pembelajaran matematika sangat cocok karena dapat memperjelas pemahaman peserta didik terhadap konsepkonsep matematika maupun keterkaitan antar konseptersebut.

Berdasarkan hasil uji serta pembahasan di atas, dapat disimpulkan bahwa Hasil belajar matematika pada materi kesebangunan dan kekongruenan yang diajarkan dengan peta konseplebih baikdari pada yang diajarkan dengan metode konvensional pada masing-masing peserta didik dengan kreativitas tinggi, sedang dan rendah. Atau dengan kata lain dapat dinyatakan sebagai berikut: (1) Pada peserta didik dengan kreativitas tinggi, hasil belajar matematika yang diajarkan dengan peta konsep lebih baik dari pada hasil belajar matematika yang diajarkan dengan metode konvensional. (2) Pada peserta didik dengan kreativitas sedang, hasil belajar matematika yang diajarkan dengan peta konsep lebih baik dari padahasil belajar matematika yang diajarkan dengan metode konvensional. Pada peserta didik dengan kreativitas rendah, hasil belajar matematika yang diajarkan dengan peta konsep lebih baik dari padahasil belajar matematika yang diajarkan dengan metode konvensional. Hal ini sejalan dengan hasil penelitian dari (Yanti,2009), strategi peta konsep data meningkatkan pemahaman pada konsep fungsi komposisi. Hasil penelitian ini juga didukung oleh hasil penelitian (Asmaningruma dkk, 2018), yang menyimpulkan terdapat peningkatan hasil belajar kimia melalui media peta konsep pada materi pokok ikatan kimia.

\section{SIMPULAN DAN SARAN}

\section{SIMPULAN}

Hasil belajar matematika peserta didik yang diajar dengan peta konsep pada materi kesebangunan dan kekongruenan lebih baik daripada hasil belajar matematika yang diajar dengan metode konvensional.

\section{SARAN}

Pembelajaran dengan penggunaan peta konsep dapat dijadikan salah satu alternatif dalam meningkatkan hasil belajar peserta didik.

\section{UCAPAN TERIMA KASIH}

Ucapan terimakasih kepada Kepala Sekolah SMP Negeri 2 Jayapura yang memberikan kesempatan untuk mengadakan penelitian disekolah tersebut. 


\section{DAFTAR PUSTAKA}

Asmaningruma H P, Gelonga $\mathrm{M}$ A, dan Werang B R, 2018, Penerapan Media Peta Konsep Terhadap Hasil Belajar Siswa SMA Geradus Adii Merauke, Jurnal Inovasi Pend. Kimia, v. 12, n. 2, $2224-2238$;

Budiyono, 1990, Statistika untuk Penelitian Edisi ke-2, Surakarta: Sebelas Maret UniversityPress;

Heriawan A, Darmajari, dan Senjaya A, 2012, Metodologi Pembelajaran Kajian Teoritis Praktis (Ed), Banten: LP3G;

Setiawati E, 2005, Meningkatkan Kemampuan Pemahaman dan Kemampuan PemecahanMasalah Matematika melalui Teknik SQ4R dan Peta Konsep Peserta didik Madrasah Aliyah. (Tesis). Bandung: Universitas Pendidikan Indonesia;
Trihendardi C, 2013, Langkah Mudah Menguasai SPSS 21, Andi, Yogyakarta;

Usman M U, 2001, Menjadi Guru Profesional. Bandung: Remaja Rosdakarya;

Yanti S. 2009, mplementasi Strategi Peta Konsep dalam Usaha Membangun Pemahaman Konsep Fungsi Komposisi, Masters thesis, Universitas Negeri Malang. 